PEDAGÓGUSKÉPZÉS, 10-11 (39-40), 2012-2013. 233-236.

\title{
DIGITÁLIS NEMZEDÉK KONFERENCIA 2013
}

\author{
LÉVAI DóRA \\ az Eötvös Loránd Tudományegyetem Pedagógiai és Pszichológiai Karának \\ tanársegédje \\ levai.dora@ppk.elte.hu
}

2013. március 2-án az ELTE Pedagógiai és Pszichológiai Kar Kazinczy utcai épülete adott otthont a második alkalommal megrendezett „Digitális nemzedék konferencia" elnevezésü szakmai eseménynek. A konferencia - az előző évi rendezvény folytatásaként - arra kereste a választ, hogy a pedagógusnak az iskolában és azon kívül milyen feladatai, lehetőségei vannak a digitális nemzedék tanulóival való közös tevékenység során. Az elmúlt években számos szakmai diskurzus indult a digitális generációk oktatásának és nevelésének témaköréhez kapcsolódóan, egyre szélesebb a témával foglalkozó szakmai események, online közösségek, honlapok köre.

A „Digitális nemzedék konferencia” (http://digitalisnemzedek.hu/) egy olyan szakmai konferenciasorozat, amely pedagógusok, oktatáskutatók, nevelésszociológusok, pszichológusok, gyógypedagógusok, szociális szakemberek, szülők és leendő tanárok párbeszédére teremt lehetőséget, amely párbeszéd keretében azonosítjuk azokat a jelenségeket, amelyek az általunk tanított és nevelt digitális generációra igazak. A különböző digitális generációkat leíró elméletek egy része meginogni látszik, mások új kategóriákkal bővítik a már kialakult csoportosításokat, de abban mindenki egyetért, hogy a digitális generációkat a korábbiaktól eltérő módszerekkel, más tanári attitüddel, szemléletváltással kell tanítani és nevelni.

A 2013-as konferencia kiemelt témakörei:

- Digitális állampolgárság.

- Életkori különbségek a netgeneráció tagjai között.

- Hátrányos helyzet és esélyegyenlőség.

- Digitális írástudás.

- A Microsoft eszközei és tanulástámogató lehetőségei.

- Fókuszban a közösség. A megújult Sulinet portál lehetőségei.

- Magyartanítás a digitális generációk körében.

- Médiaoktatás a digitális generációk körében.

A témakörök iránti érdeklődést mutatja, hogy a rendezvényre idén több mint négyszáz pedagógusjelölt, pedagógus, szülö, diák, hallgató és érdeklődő regisztrált. A konferencián délelött három plenáris előadást hallhattunk, valamint egy rövid bemutató idejére lehetőséget kaptak a konferencián kiállító szervezetek is, akik a pedagógusok 
számára hasznos, a mindennapi tanítást is kiegészítő információkkal, programlehetőségekkel szolgáltak.

Ujhelyi Adrienn plenáris előadásában arra kereste a választ, hogy hogyan alakul a digitális identitásunk, mit tehetünk annak érdekében, hogy a rólunk kialakult kép tükrözze a valódi énünket, milyen szabályokat és etikettet kell betartanunk annak érdekében, hogy online közösségekben hitelesek lehessünk. Kitért a nemzedékek közötti ellentétekre, és arra, hogy az elkövetkező pár évben már az első generációs „digitális bennszülöttek" válnak szülővé, amely újabb érdekes jelenségeket hoz majd magával.

Az Y diagnózis csapatából három fiatal (Csányi Márton, Nagyistók Máté, Nyárai Gerzson) tartott előadást arról, hogy a digitális bennszülötteket mely kérdések foglalkoztatják a leginkább, és milyen tájékoztató jellegủ előadásokat, beszélgetéseket szerveznek számukra annak érdekében, hogy minél többet megtudjanak a mai középiskolások és általános iskolások például a testképpel kapcsolatos kérdésekröl és változásokról, a dohányzásról, alkoholról, szexuális viselkedésről. Az Y diagnózis csapata olyan - a fiatalokat érintő - kérdésekkel foglalkozik, amelyek feltárása és bemutatása az iskola pedagógusainak nagy segítséget jelenthet. Szórakoztató és egyben figyelemfelhívó előadásaikat a Facebookon több, mint 30 ezren követik, népes „rajongótáboruk” van.

Z. Karvalics László plenáris előadásában három mesehőssel (Hamupipőke, Piroska, mangalány) és az ahhoz kapcsolódó világképekkel foglalkozott, amelyek alakítják az adott kor társadalmáról és az oktatásról vallott nézeteinket. Egyfajta tükröt tartott a közönség elé, amely tükörben felismerhettük az egyes korok visszatükröződő szépséghibáit és szépségét egyaránt.

„Piroska ízig-vérig a premodern gyermeke. (...) Disney-Hamupipőke a kibontakozó indusztriális világ szülötte és megtestesítője. (...) A Mangalány egészen különleges világban él. Életének két dolog ad keretet: a kortársközösség, amely a kisebb rivalizálások és versenyek ellenére a legfontosabb támogató - visszajelző - identitásképző elem, és a célvezéreltség, amely »kifelé« küldetésekben, missziókban, akciókban testesül meg, »befelé« pedig az önfejlesztés, az ön-tökéletesítés programjában. Szinte örök Jelenben élnek, a Múlt és a felnőtt társadalom irreleváns, de azért a háttérből sugároznak pozitív üzeneteket. (...)" (Idézetek az előadásokból)

A konferencia teljes délelőtti programja (a plenáris előadásokkal és a bemutatókkal együtt) utólag is megtekinthetö - felvételröl - a konferencia honlapján. A plenáris előadók tanulmányait, valamint a konferencia előadóinak absztraktjait magába foglaló konferenciakötet elérhető online lapozható és letölthető formában is a konferencia honlapjáról, ugyanitt elérhetőek a konferencia délutáni szekcióiban bemutatott előadások prezentációi is, valamint a konferenciáról - mások billentyüzetéből - megjelent írások is. A konferenciához kapcsolódóan müködő, nyilvános online közösség a https://www.facebook.com/digitalispedagogus címen érhető el, ahová szeretettel várjuk további érdeklődők csatlakozását. 
A délután során kétszer másfél óra keretében nyolc-nyolc szekciófoglalkozásra került sor, amely foglalkozások keretében minden érdeklődő megtalálhatta az öt leginkább érdeklő témákat és előadókat. A délutáni szekciók témái között foglalkoztunk a médiatanítás és a magyartanítás lehetőségeivel a digitális korban, megismerkedhettünk a Sulinet lehetőségeivel, pedagógusok bemutatták, hogy a Microsoft eszközei hogyan használhatóak a tanítás és tanulás támogatására, foglalkoztunk digitális írástudással, digitális biztonsággal, a digitális nemzedék szülőszerepével, a hátrányos helyzetü tanulók fejlesztésének digitális lehetőségeivel, valamint azzal is, hogy milyen sajátos oktatási zavarok jelennek meg a digitális nemzedék körében.

A délután folyamán közelebbről megismerkedtünk a ,jövő osztálytermével”, közösen formáltuk a digitális biztonsággal kapcsolatos nézeteinket, amelyhez kapcsolódóan egy Facebook-csoportot is alakítottunk (www.facebook.com/groups/digitalisbiztonsag). Gyakorló pedagógusok bemutatták azokat az online eszközöket, amelyekkel hatékonyabbá tehetjük a pedagógiai tervezést, csoportalakítást, kommunikációt, információmegosztást és tevékenykedtetést, beszélgettünk a szülők felelősségéről, megismertük a „Netszótár” címü kiadványt, amely egyfajta idegenvezetőként szolgál a digitális nemzedék szóhasználatához kapcsolódóan.

Az iménti felsorolás nem teljes körü, a konferencián elhangzott előadások részletes megismeréséhez és a szekciókban zajló munkába való betekintéshez lehetőséget nyújt - a konferencia honlapján - az online konferenciakötet valamint a feltöltött prezentációk.

A „Digitális nemzedék konferencia 2013” szervezöi az ELTE Pedagógiai és Pszichológiai Kar, Iskolapedagógiai Központ, Információs Társadalom Oktató- és Kutatócsoport, az Educatio Társadalmi Szolgáltató Nonprofit Kft., az Osztályfőnökök Országos Szakmai Egyesülete és a Magyartanárok Egyesülete.

A konferencia programbizottságának tagjai: Lévai Dóra (a programbizottság elnöke, ELTE PPK Iskolapedagógiai Központ), Ollé János (ELTE PPK Iskolapedagógiai Központ), Tóth-Mózer Szilvia (Educatio Társadalmi Szolgáltató Nonprofit Kft.), Főző Attila László (Educatio Társadalmi Szolgáltató Nonprofit Kft.), Szekszárdi Júlia (Osztályfönökök Országos Szakmai Egyesülete), Peer Krisztina (Osztályfőnökök Országos Szakmai Egyesülete), Fenyő D. György (Magyartanárok Egyesülete).

A konferencia „testvérrendezvénye” a „Digitális pedagógus konferencia”, amelynek 2013. május 25-én rendezzük a második rendezvényét az Eötvös Loránd Tudományegyetem Pedagógia és Pszichológia Karán. Hamarosan aktuális információkkal szolgálunk a konferencia honlapján (http://digitalispedagogus.hu/), ahol jelenleg elérhetőek a „Digitális pedagógus konferencia 2012” előadásai, a tanulmánykötet, illetve minden konferenciával kapcsolatos információ.

Míg a „Digitális nemzedék konferencia” elnevezésű rendezvénysorozat arra keresi a választ, hogy a pedagógusoknak és szülőknek milyen együttmüködési, 
kommunikációs, tanulási és tanítási lehetőségei vannak a digitális nemzedék tanulóival, addig a „Digitális pedagógus konferencia” a pedagógusok saját, szakmai tevékenységével kapcsolatban foglalkozik elméleti és gyakorlati kérdésekkel, amelyek a tanári kompetenciák felöl világítanak rá arra, hogy milyen legyen a 21. század pedagógusa. 